\title{
PENGARUH PARTISIPASI ANGGARAN, PENEKANAN ANGGARAN, DAN KOMITMEN ORGANISASI TERHADAP SENJANGAN ANGGARAN PADA SUKU DINAS PEMERINTAHAN DI DKI JAKARTA
}

\author{
I Gede Eka Dharma Putra ${ }^{1)}$ \\ Danang Mintoyuwono ${ }^{2)}$ \\ Universitas Pembangunan Nasional "Veteran" Jakarta,
}

\begin{abstract}
The study aims to determine the influence of budgetary participation, budget emphasis and organisation commitment on budgetary slcak. Respondents were studied were departement chief, head of subsection, and section chief in departements at west jakarta, south jakarta, north jakarta, central jakarta, and east jakarta. Data collection techniques in this research using primary data by distributing questionnaires to 211 respondents. Technique data processing was performed using SPSS 21 and assisted by using microsoft office 2010. The variables studied consisted of budgetary participation, budget emphasis, organisation commitment and budgetary slack. The analysis used to test this research is multiple linear regression test. Partial results of the study showed absence of budgetary participation significant effect on budgetary slack, the absence of budget emphasis on budgetary slack, and absence of organisation commitment on budgetary slack. From the results of simultaneous studies showed a significant effect between the variables of budgetary participation, budget emphasis, organisation commitment on budgetary slack.
\end{abstract}

Keywords : budgetary participation, budget emphasis, organisation commitment and budgetary slack.

\section{PENDAHULUAN}

Di zaman modern dengan kecanggihan teknologi seperti ini, organisasi berbasis sektor publik tidak kalah pentingnya dibandingkan dengan organisasi berbasis profit. Hal ini dibuktikan dengan pemberitaan baik di media elektronik, cetak, bahkan media sosial yang sangat gencar dengan pemberitaan mengenai organisasi berbasis sektor publik baik pemerintah pusat maupun pemerintah daerah. Hal ini dibuktikan dalam Peraturan Pemerintah Nomor 71 Tahun 2010 mengenai pengguna laporan keuangan pemerintah diantaranya masyarakat, wakil rakyat, lembaga pengawas, lembaga pemeriksa, pihak yang memberi atau berperan dalam proses donasi, investasi, dan pijaman serta pemerintah itu sendiri.

'Anggaran sektor publik merupakan instrumen akuntabilitas atas pengelolaan dana publik dan pelaksanaan program-program yang dibiayai dengan uang publik' (Mardiasmo 2009, hlm. 61).

Anggaran sektor publik yang bersifat terbuka terhadap masyarakat luas tidak kalah penting daripada anggaran yang biasanya bersifat tertutup didalam organisasi berbasis profit. Dalam penyusunan anggaran, prilaku-prilaku manusia akan timbul seiring dengan berjalannya proses-proses penganggaran baik yang bersifat positif maupun negatif. Menurut Anggraeni (2008) dalam Dewi \& Sudana (2013) prilaku positif akan muncul jika karyawan memiliki motivasi tinggi untuk mencapai anggaran tersebut yang berakibat pada penilaian peningkatan kinerja mereka. Sedangkan prilaku 
negatif akan muncul ketika karyawan merasa terbebani dengan anggaran yang harus dicapai sehingga berakibat terjadinya senjangan anggaran.

Pada akhir tahun 2015 persoalan mengenai anggaran di DKI Jakarta kembali memanas. Anggota badan anggaran DPRD DKI Jakarta memberikan kritik terhadap Satuan Kerja Perangkat Daerah (SKPD) yang membuat anggaran untuk program senam tahun 2016 di Dinas Kelautan, Pertanian, dan Ketahanan Pangan. Anggaran yang diajukan oleh Dinas Kelautan, Pertanian, dan Ketahanan Pangan untuk program pembinaan jasmani dan rohani yang memang dianggarkan sebesar Rp. 258 juta. Menurut anggota DPRD, biaya yang dikeluarkan sebesar RP. 258 juta sangatlah memberatkan dan tidak sejalan dengan semangat gurbenur yang menginginkan efisiensi dalam anggaran yang digunakan.

Anggaran yang dibuat oleh atasan dan bawahan seharusnya bisa meminimalisir terjadinya senjangan anggaran. Dalam pembuatan anggaran di instansi pemerintahan, semua pihak baik pemda DKI maupun DPRD DKI terlibat langsung dalam proses penyusunan hingga pengesahannya. Sehingga partisipasi yang dilakukan oleh atasan dalam hal ini DPRD seharusnya mampu meminimalisir terjadinya senjangan anggaran. Selain itu jika berbicara tentang komitmen organisasi, maka kemauan untuk bekerja di organisasi sektor publik khususnya di DPRD maupun pemda sangatlah tinggi. Hal ini dibuktikan dengan semakin tingginya orang-orang yang berebut kursi setiap ada pemilihan anggota DPRD maupun perekrutan sebagai CPNS di SKPD DKI Jakarta. Dengan motivasi tinggi untuk berada di lingkungan kerja sektor publik, maka seharusnya senjangan anggaran dapat dikurangi.

Dalam instansi pemerintah, setiap pihak baik DPRD maupun pemda DKI wajib bekerjasama dalam proses pembuatan anggaran. Sehingga istilah penekanan anggaran seharusnya tidak ada. Hal ini disebabkan atasan atau DPRD tidak berhak untuk memberikan reward atau sangsi jika anggaran yang telah disetujui tidak tercapai. Jadi seharusnya senjangan anggaran dalam instansi pemerintah dapat di minimalisir bahkan seharusnya tidak ada.

Berdasarkan uraian yang telah dikemukakan diatas, maka permasalahan pokok yang akan diteliti sebagai berikut:
a. Apakah Partisipasi Anggaran memiliki pengaruh terhadap Senjangan Anggaran?
b. Apakah Penekanan Angaran memiliki pengaruh terhadap Senjangan Anggaran?
c. Apakah Komitmen Organisasi memiliki pengaruh terhadap Senjangan Anggaran?

\section{TINJAUAN PUSTAKA \\ Teori Sinyal (Signaling Theory)}

Penjelasan tentang anggaran dapat dimulai dari teori sinyal (signaling theory) di mana anggaran publik yang telah di publikasikan dapat mempengaruhi keputusan seseorang untuk berinvestasi di suatu daerah atau negara, jika rencana program dalam anggaran yang ditetapkan akan memberikan sinyal positif terhadap para investor. Menurut Fahmi \& Hadi (2009, hlm. 83) tanggapan para investor terhadap sinyal positif dan negatif akan sangat mempengaruhi kondisi suatu objek tertentu, dalam hal ini suatu daerah atau suatu negara. 


\section{Teori Keagenan (Agency Theory)}

Menurut Harahap (2012, hlm. 532) teori ini menyebutkan bahwa organisasi adalah tempat bagi hubungan kontrak yang terjadi antara beberapa pihak yang terlibat didalamnya. Dalam organisasi sektor publik, DPR/DPRD bertindak sebagai prinsipal sementara Pemerintah pusat maupun daerah bertindak sebagai agen. Pemerintah pusat dan daerah terlibat dalam proses penyusunan hingga pelaporan anggaran sedangkan pihak DPR dan DPRD terlibat dalam proses pengesahan dan pengawasan yang aktif dilakukan.

\section{Senjangan Anggaran (Budgetary Slack)}

Senjangan anggaran adalah praktik yang dilakukan oleh penyusun anggaran dengan sengaja memasukkan jumlah pengeluaran lebih besar dan jumlah pendapatan lebih kecil ke dalam anggaran. Jika jumlah biaya atau pendapatan aktual di realisasikan dan dibandingkan dengan figur yang dianggarkan maka menunjukkan penampilan usaha yang berhasil (Blocher, Stout \& Cokins 2011, hlm. 612).

Senjangan anggaran dapat dipengaruhi oleh beberapa faktor seperti partisipasi anggaran, penekanan anggaran, komitmen organisasi, kejelasan sasaran anggaran, locus of control, budgetary control, ketidakpastian strategik, informasi asimetri, ketidakpastian lingkungan, Group Cohesivness dan lain-lain.

\section{Pengaruh Partisipasi Anggaran Terhadap Senjangan Anggaran}

Partisipasi anggaran merupakan proses dimana satuan kerja baik itu atasan maupun bawahan yang terlibat dan mempunyai pengaruh dalam menentukan target anggaran' (Apriantini dkk, 2014).

Penelitian tentang pengaruh antara partisipasi anggaran terhadap senjangan anggaran telah banyak dilakukan diantaranya: Young (1985), Ikhsan \& Ane (2007), Triana dkk, (2012), Dewi \& Sudana (2013), dan Apriantini dkk, (2014) yang menunjukan variabel partisipasi anggaran berpengaruh secara signifikan positif terhadap senjangan anggaran. Artinya senjangan anggaran terjadi karena pihak-pihak yang terlibat dalam penyusunan anggaran memberikan informasi yang bias dengan cara melaporkan biaya yang lebih tinggi dan pendapatan yang lebih rendah agar target anggaran tercapai.

Berdasarkan teori dan hasil penelitian sebelumnya maka hipotesis yang dapat dikembangkan adalah sebagai berikut:

$\mathrm{H}_{1}$ : Partisipasi Anggaran berpengaruh signifikan positif terhadap Senjangan Anggaran.

\section{Pengaruh Penekanan Anggaran Terhadap Senjangan Anggaran}

Menurut Savitri \& Sawitri (2014) menyatakan bahwa 'penekanan anggaran merupakan desakan dari atasan pada bawahan untuk melaksanakan anggaran yang telah dibuat dengan baik'. Jadi penekanan anggaran dilakukan oleh atasan terhadap bawahan untuk menjalankan suatu anggaran tersebut dengan baik, sehingga anggaran yang ditetapkan dapat tercapai. Jika anggaran tersebut dapat tercapai, maka bawahan akan diberikan reward atau kompensasi namun jika target anggaran tidak terpenuhi maka bawahan akan diberikan sebuah sanksi. Penelitian tentang hubungan antara penekanan anggaran terhadap senjangan anggaran telah banyak dilakukan diantaranya: Triana dkk, (2012) dan Apriantini dkk, (2014) yang menunjukan variabel penekanan anggaran berpengaruh secara signifikan positif terhadap senjangan anggaran. Artinya semakin 
tinggi penekanan yang dilakukan oleh atasan terhadap bawahan untuk menjalankan anggaran tersebut dengan baik, maka tingkat kesenjangan anggaran juga semakin besar.

Berdasarkan teori dan hasil penelitian sebelumnya maka hipotesis yang dapat dikembangan adalah sebagai berikut:

$\mathrm{H}_{2}$ : Penekanan Anggaran berpengaruh signifikan positif terhadap Senjangan Anggaran.

\section{Pengaruh Komitmen Organisasi Terhadap Senjangan Anggaran}

Komitmen organisasi merupakan tingkat sampai sejauh apa seorang karyawan memihak pada suatu organisasi tertentu dan tujuan-tujuannya, serta berniat mempertahankan keanggotannya dalam organisasi tersebut (Lubis 2010, hlm. 54). Penelitian tentang hubungan antara komitmen organisasi terhadap senjangan anggaran telah banyak dilakukan diantaranya: Dewi \& Sudana (2013), Apriantini dkk, (2014), Dewi \& Erawati (2014), dan Mahadewi (2014) yang menunjukan variabel komitmen organisasi berpengaruh secara signifikan negatif terhadap senjangan anggaran. Artinya semakin tinggi komitmen organisasi setiap individu, maka tingkat kesenjangan anggaran juga semakin menurun.

Berdasarkan teori dan hasil penelitian sebelumnya maka hipotesis yang dapat dikembangkan adalah sebagai berikut:

$\mathrm{H}_{3}$ : Komitmen Organisasi berpengaruh signifikan negatif terhadap Senjangan Anggaran

\section{METODE PENELITIAN}

\section{Definisi Dan Pengukuran Variabel}

Senjangan anggaran adalah praktik yang dilakukan oleh penyusun anggaran dengan sengaja memasukkan jumlah pengeluaran lebih besar dan jumlah pendapatan lebih kecil ke dalam anggaran (Blocher et.al 2011, hlm. 612). Variabel senjangan anggaran yang digunakan sebagai variabel dependen dalam penelitian ini diukur dengan menggunakan instrumen yang dikembangkan oleh Dunk (1993) dalam Triana dkk, (2012).

\section{a. Partisipasi Anggaran $\left(\mathrm{X}_{1}\right)$}

'Partisipasi anggaran merupakan proses dimana satuan kerja baik itu atasan maupun bawahan yang terlibat dan mempunyai pengaruh dalam menentukan target anggaran' (Apriantini dkk, 2014). Variabel partisipasi anggaran yang digunakan sebagai variabel independen dalam penelitian ini diukur dengan menggunakan instrumen yang dikembangkan oleh Milani (1975) dalam penelitian Triana dkk, (2012).

b. Penekanan Anggaran $\left(\mathrm{X}_{2}\right)$

'Penekanan anggaran merupakan desakan dari atasan pada bawahan untuk melaksanakan anggaran yang telah dibuat dengan baik' (Savitri \& Sawitri 2014). Variabel penekanan anggaran yang digunakan sebagai variabel independen dalam penelitian ini diukur dengan menggunakan instrumen yang dikembangkan oleh Hopwood (1972) dalam Triana dkk, (2012).

c. Komitmen organisasi $\left(\mathrm{X}_{3}\right)$

'komitmen organisasi merupakan tingkat sampai sejauh apa seorang karyawan memihak pada suatu organisasi tertentu dan tujuan-tujuannya, serta berniat mempertahankan keanggotannya dalam organisasi tersebut' (Lubis 2010, hlm. 54). Variabel komitmen organisasi yang digunakan sebagai variabel independen dalam penelitian ini diukur dengan menggunakan instrumen yang dikembangkan oleh Cook \& Wall (1980). 


\section{Populasi Dan Sampel}

Populasi yang akan digunakan dalam penelitian ini adalah Suku Dinas Pemerintahan di wilayah DKI Jakarta. Sampel yang digunakan dalam penelitian ini adalah orang-orang yang berkaitan langsung dalam proses penyusunan anggaran seperti kepala suku dinas, kepala sub bagian, kepala seksi, sehingga sesuai dengan teknik purposive sampling dimana mengharuskan seorang ahli sebagai sampel yang benar-benar menguasai suatu masalah yang akan di teliti.

\section{HASIL DAN PEMBAHASAN}

Tabel 1. Distribusi Kuesioner

\begin{tabular}{lcc}
\hline \multicolumn{1}{c}{ Keterangan } & Jumlah & Persentase \\
\hline Jumlah kuesioner yang disebar & 211 & $100 \%$ \\
\hline Jumlah kuesioner yang kembali & 139 & $66 \%$ \\
\hline Jumlah kuesioner yang tidak kembali & 72 & $34 \%$ \\
\hline Jumlah kuesioner tidak dapat diolah & 36 & $17 \%$ \\
\hline Jumlah kuesioner yang dapat diolah & 103 & $49 \%$ \\
\hline
\end{tabular}

Dari data di atas jumlah kuisioner yang berhasil disebar sebanyak 211 kuisioner. Sementara itu kuisioner yang kembali sebanyak 139 kuisioner yang berarti 72 kuisioner tidak kembali dikarenakan beberapa alasan seperti kuisioner hilang dan salah responden. Sedangkan kuisioner yang dapat diolah untuk digunakan dalam penelitian ini berjumlah 103 kuisioner.

\section{Uji Kualitas Data}

Tabel 2. Statistik Deskriptif

Descriptive Statistics

\begin{tabular}{lccccc}
\hline & $\mathrm{N}$ & Minimum & Maximum & Mean & $\begin{array}{c}\text { Std. } \\
\text { Deviation }\end{array}$ \\
\hline Senjangan Anggaran & 103 & 13 & 30 & 20,63 & 3,378 \\
\hline Partisipasi Anggaran & 103 & 16 & 30 & 23,83 & 3,142 \\
\hline Penekanan Anggaran & 103 & 20 & 40 & 33,42 & 3,996 \\
\hline Komitmen Organisasi & 103 & 25 & 45 & 37,37 & 4,111 \\
\hline Valid N (listwise) & 103 & & & & \\
\hline \multicolumn{1}{c}{ Sumber: Data diolah dari SPSS 21 }
\end{tabular}

Dari tabel 2 dapat diketahui bahwa N sebesar 103 artinya jumlah data yang digunakan dalam penelitian ini berjumlah 103 responden.

Tabel 2 menunjukkan nilai minimum Senjangan Anggaran sebesar 13, nilai maksimum sebesar 30, dan nilai mean (rata-rata) sebesar 20,63 yang apabila dibagi dengan 6 butir pernyataan diperoleh nilai sebesar 3,44 yang dibulatkan menjadi 3, maka dapat diperoleh rata-rata jawaban responden adalah pada skala 3 (cukup benar). Dapat disimpulkan bahwa rata-rata jawaban responden tentang senjangan anggaran adalah 3 atau cukup benar artinya senjangan anggaran terjadi.

Pada variabel Partisipasi Anggaran menunjukkan nilai minimum 16, nilai maksimum sebesar 30, dan nilai mean (rata-rata) sebesar 23,83 yang apabila dibagi dengan 6 butir pernyataan diperoleh nilai sebesar 3,97 yang dibulatkan menjadi 4, maka dapat diperoleh 
jawaban responden adalah pada skala 4 (benar). Dapat disimpulkan bahwa responden sudah ikut berpartisipasi dalam pembuatan anggaran dalam suatu organisasi.

Pada variabel Penekanan Anggaran menunjukkan nilai minimum 20, nilai maksimum sebesar 40, dan nilai mean (rata-rata) sebesar 33,42 yang apabila dibagi dengan 8 butir pernyataan diperoleh nilai sebesar 4,18 yang dibulatkan menjadi 4 , maka dapat diperoleh jawaban responden adalah pada skala 4 (penting). Dapat disimpulkan bahwa penekanan yang ada dalam anggaran tinggi.

Pada variabel Komitmen Organisasi menunjukkan nilai minimum 25, nilai maksimum sebesar 45, dan nilai mean (rata-rata) sebesar 37,37 yang apabila dibagi dengan 9 butir pernyataan diperoleh nilai sebesar 4,15 yang dibulatkan menjadi 4, maka dapat diperoleh jawaban responden adalah pada skala 4 (benar). Dapat disimpulkan bahwa responden memiliki komitmen organisasi yang tinggi.

\section{Uji Validitas Dan Reliabilitas}

Setelah mendapatkan hasil data kuesioner dari responden, maka dilakukan uji validitas, sebagai berikut :

Tabel 3. Hasil Uji Validitas

\begin{tabular}{|c|c|c|c|}
\hline Butir Pernyataan & Pearson Correlation & Sig. (2-tailed) & Keterangan \\
\hline \multicolumn{4}{|c|}{ Variabel Partisipasi Anggaran per item $\left(\mathrm{X}_{1}\right)$} \\
\hline PA1 & $0,726^{* *}$ & 0,000 & Valid \\
\hline PA2 & $0,779^{* *}$ & 0,000 & Valid \\
\hline PA3 & $0,745^{* *}$ & 0,000 & Valid \\
\hline PA4 & $0,752^{* *}$ & 0,000 & Valid \\
\hline PA5 & $0,752^{* *}$ & 0,000 & Valid \\
\hline PA6 & $0,760^{* *}$ & 0,000 & Valid \\
\hline \multicolumn{4}{|c|}{ Variabel Penekanan Anggaran per item $\left(\mathrm{X}_{2}\right)$} \\
\hline PEA1 & $0,617^{* *}$ & 0,000 & Valid \\
\hline PEA2 & $0,653^{* *}$ & 0,000 & Valid \\
\hline PEA3 & $0,681^{* *}$ & 0,000 & Valid \\
\hline PEA4 & $0,680^{* *}$ & 0,000 & Valid \\
\hline PEA5 & $0,735^{* *}$ & 0,000 & Valid \\
\hline PEA6 & $0,553^{* *}$ & 0,000 & Valid \\
\hline PEA7 & $0,703^{* *}$ & 0,000 & Valid \\
\hline PEA8 & $0,689^{* *}$ & 0,000 & Valid \\
\hline \multicolumn{4}{|c|}{ Variabel Komitmen Organisasi per item $\left(\mathrm{X}_{3}\right)$} \\
\hline KO1 & $0,567^{* *}$ & 0,000 & Valid \\
\hline $\mathrm{KO} 2$ & $0,723^{* *}$ & 0,000 & Valid \\
\hline $\mathrm{KO} 3$ & $0,608^{* *}$ & 0,000 & Valid \\
\hline KO4 & $0,743^{* *}$ & 0,000 & Valid \\
\hline KO5 & $0,733^{* *}$ & 0,000 & Valid \\
\hline KO6 & $0,747^{* *}$ & 0,000 & Valid \\
\hline $\mathrm{KO} 7$ & $0,722^{* *}$ & 0,000 & Valid \\
\hline KO8 & $0,730^{* *}$ & 0,000 & Valid \\
\hline KO9 & $0,651^{* *}$ & 0,000 & Valid \\
\hline \multicolumn{4}{|c|}{ Variabel Senjangan Anggaran per item (Y) } \\
\hline SA1 & $0,511^{* *}$ & 0,000 & Valid \\
\hline SA2 & $0,695^{* *}$ & 0,000 & Valid \\
\hline SA3 & $0,574^{* *}$ & 0,000 & Valid \\
\hline SA4 & $0,554^{* *}$ & 0,000 & Valid \\
\hline SA5 & $0,473^{* *}$ & 0,000 & Valid \\
\hline SA6 & $0,684^{* *}$ & 0,000 & Valid \\
\hline
\end{tabular}


Berdasarkan tabel 3 diatas, hasil uji validitas menunjukkan bahwa seluruh butir pernyataan terkait variabel partisipasi anggaran, penekanan anggaran, komitmen organisasi serta senjangan anggaran dikatakan valid karena hasil signifikan Sig. (2tailed) di bawah 0,01 .

\section{Uji Reliabilitas}

Uji Reliabilitas dimaksudkan untuk mengetahui sejauh mana pengukuran jawaban yang diberikan responden adalah konsisten. Pengujian reliabilitas dapat dilakukan dengan melihat nilai Cronbach Alpha. Pengambilan keputusan yang mengatakan reliable berdasarkan nilai Cronbach Alpha $\geq 0,60$.

Tabel 4. Hasil Uji Reliabilitas

\begin{tabular}{lcc}
\hline \multicolumn{1}{c}{ Variabel } & $\begin{array}{c}\text { Cronbach's } \\
\text { Alpha }\end{array}$ & Keterangan \\
\hline Senjangan Anggaran & 0,605 & Reliable \\
\hline Partisipasi Anggaran & 0,844 & Reliable \\
\hline Penekanan Anggaran & 0,809 & Reliable \\
\hline Komitmen Organisasi & 0,849 & Reliable \\
\hline
\end{tabular}

Berdasarkan tabel 4 dapat disimpulkan bahwa variabel Senjangan Anggaran, Partisipasi Anggaran, Penekanan Anggaran, dan Komitmen Organisasi memiliki status reliabel. Hal ini dikarenakan nilai Cronbach Alpha semua variabel tersebut $\geq 0,60$. Kondisi ini juga memberikan arti bahwa seluruh variabel tersebut dapat digunakan pada analisis berikutnya.

\section{Uji Normalitas}

Uji normalitas dilakukan dengan menggunakan analisis P-Plot Regression Standarized Residual dan Kolmogorov Smirnov (K-S). Hasil normalitas dengan menggunakan analisis P-Plot Regression Standarized Residual ditunjukan dengan grafik sebagai berikut :

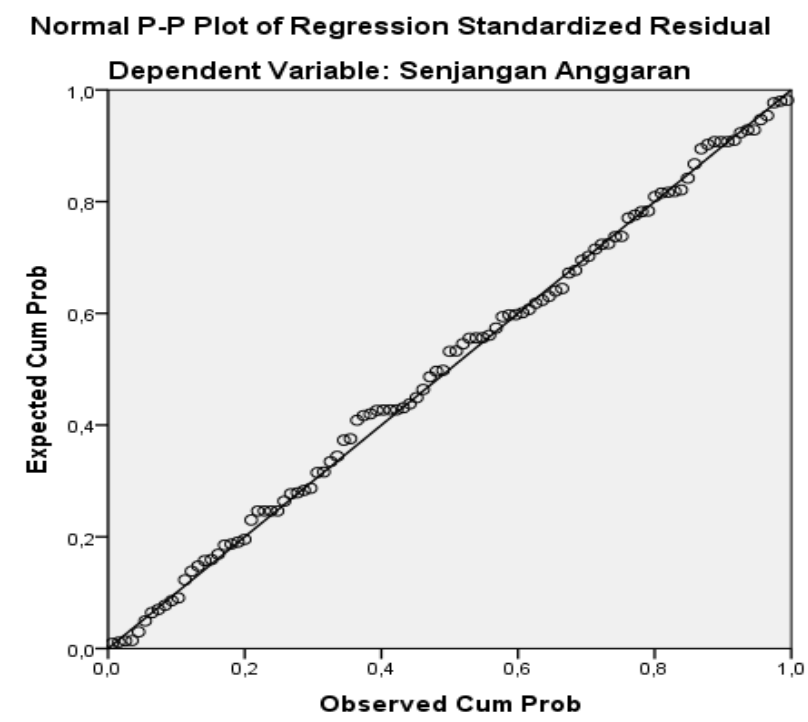

Gambar 1. Grafik P-Plot 
Berdasarkan tampilan grafik Normal P-P Plot diatas, terlihat dari titik-titik yang menyebar disekitar garis diagonal dan penyebaran mengikuti arah garis dan terlihat bahwa grafik membentuk garis yang mengarah ke angka 0 (nol) dan berdistribusi secara normal, maka model regresi memenuhi asumsi normalitas.

Tabel 5. Hasil Uji Normalitas dengan Kolmogorov-Smirnov One-Sample Kolmogorov-Smirnov Test

\begin{tabular}{lll}
\hline & & $\begin{array}{l}\text { Unstandardize } \\
\text { d Residual }\end{array}$ \\
\hline $\mathrm{N}$ & & 103 \\
\hline \multirow{2}{*}{ Normal Parameters $^{a, b}$} & Mean &, 0000000 \\
\cline { 2 - 3 } & $\begin{array}{l}\text { Std. } \\
\text { Deviation }\end{array}$ & 3,08467555 \\
\hline \multirow{2}{*}{ Most Extreme Differences } & Absolute &, 048 \\
\cline { 2 - 3 } & Positive &, 026 \\
\cline { 2 - 3 } & Negative &,- 048 \\
\hline Kolmogorov-Smirnov $Z$ & &, 488 \\
\hline Asymp. Sig. (2-tailed) &, 971 \\
\hline
\end{tabular}

a. Test distribution is Normal.

b. Calculated from data.

Sumber: Data diolah dari SPSS 21

Berdasarkan hasil perhitungan menggunakan pengujian Kolmogorov-Smirnov menunjukkan model regresi memenuhi asumsi normalitas. Hal ini dapat dilihat bahwa hasil perhitungan nilai sig atau signifikasi (nilai probabilitas) $>0,05$ yaitu $(0,971>0,05)$ artinya data berdistribusi normal.

\section{Uji Multikolinearitas}

Uji multikolonieritas dilakukan dengan menghitung nilai Variance Inflation Factor (VIF) dan tolerance. Multikolonieritas terjadi jika nilai VIF diatas 10 dan tolerance dibawah 0,10 maka salah satu variabel harus dikeluarkan dari persamaan. Namun jika VIF kurang dari 10 dan tolerance lebih dari 0,10 menunjukkan bahwa korelasi antar variabel independen masih bisa di tolerir.

Tabel 6. Hasil Uji Multikolonieritas

\begin{tabular}{llll}
\multicolumn{4}{c}{ Coefficients $^{a}$} \\
\hline \multirow{2}{*}{ Model } & \multicolumn{2}{c}{ Collinearity Statistics $^{\text {Tolerance }}$} & VIF \\
\hline \multirow{3}{*}{1} & & & \\
\cline { 2 - 4 } & (Constant) & & \\
\cline { 2 - 4 } & Partisipasi Anggaran &, 513 & 1,950 \\
\cline { 2 - 4 } & Penekanan Anggaran &, 486 & 2,059 \\
\cline { 2 - 4 } & Komitmen Organisasi &, 534 & 1,873 \\
\hline
\end{tabular}

a. Dependent Variable: Senjangan Anggaran

Sumber: Data diolah dari SPSS 21

Berdasarkan hasil perhitungan pada tabel 6, dapat diketahui bahwa nilai tolerance pada seluruh variabel independen lebih dari 0,10 yang berarti tidak terjadi korelasi antar variabel independen dan nilai Variance Inflation Factor (VIF) dari masing-masing 
variabel independen lebih kecil dari 10, sehingga dapat disimpulkan bahwa tidak terjadinya masalah atau hubungan multikolineritas diantara variabel independen dari pernyataan untuk variabel senjangan anggaran, partisipasi anggaran, penekanan anggaran serta komitmen organisasi.

\section{Uji Heteroskedastisitas}

Uji Heteroskedastisitas bertujuan untuk menguji apakah dalam model regresi terjadi ketidaksamaan varians dari residual suatu pengamatan ke pengamatan yang lain. Deteksi ada tidaknya heteroskedastisitas pada penelitian ini dapat dilakukan dengan melihat ada tidaknya pola tertentu pada grafik scatterplot.

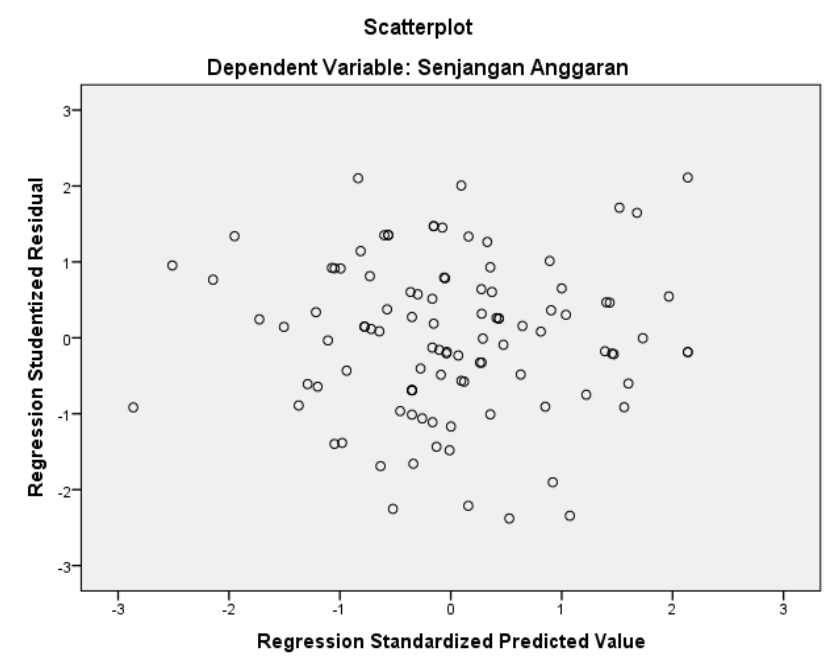

Gambar 2. Grafik Scatterplot

Berdasarkan grafik scatterplot terlihat bahwa titik-titik menyebar secara acak baik diatas maupun dibawah angka 0 pada sumbu $\mathrm{Y}$ dan tidak membentuk pola tertentu. Hal ini dapat disimpulkan bahwa tidak terjadi heteroskedastisitas pada model regresi. Selain menggunakan grafik scatterplot, pengujian heteroskedastisitas juga dapat dilakukan dengan melakukan uji glejser yang dinilai lebih akurat dibandingkan dengan menggunakan grafik scatterplot.

Tabel 7. Hasil Uji Glejser

\begin{tabular}{clc}
\multicolumn{3}{c}{ Coefficients $^{a}$} \\
\hline \multirow{3}{*}{1} & Model & Sig. \\
\hline \multirow{3}{*}{1} & (Constant) &, 152 \\
\cline { 2 - 3 } & Partisipasi Anggaran &, 372 \\
\cline { 2 - 3 } & Penekanan Anggaran &, 291 \\
\cline { 2 - 3 } & Komitmen Organisasi &, 733 \\
\hline
\end{tabular}

a. Dependent Variable: AbsUt

Sumber: Data diolah dari SPSS 21

Berdarkan tabel 7, dapat diketahui bahwa variabel partisipasi anggaran memiliki nilai signifikansi 0,372 , penekanan anggaran memiliki nilai signifikansi 0,291 , dan 
komitmen organisasi memiliki nilai signifikansi 0,733. Dari hasil ketiga variabel independen tersebut dapat disimpulkan bahwa model regresi ini tidak terjadi masalah heteroskedastisitas, karena nilai signifikansinya diatas $>0,05$.

\section{Uji Koefisien Determinasi $\left(\mathbf{R}^{2}\right)$}

Pengujian Koefisien Determinasi $\left(\mathrm{R}^{2}\right)$ bertujuan untuk mengukur seberapa besar pengaruh variabel independen yaitu Partisipasi Anggaran, Penekanan Anggaran, dan Komitmen Organisasi terhadap variabel dependen yaitu Senjangan Anggaran. Berikut ini merupakan hasil pengujian koefisien determinasi:

Tabel 8. Hasil Uji Koefisien Determinasi $\left(\mathrm{R}^{2}\right)$

\begin{tabular}{ccccc} 
Model & $\mathrm{R}$ & $R$ & $\begin{array}{c}\text { Mdjusted } R \\
\text { Square }\end{array}$ & $\begin{array}{c}\text { Std. Error of the } \\
\text { Estimate }\end{array}$ \\
\hline 1 &, $408^{\mathrm{a}}$ &, 166 &, 141 & 3,131 \\
\hline
\end{tabular}

a. Predictors: (Constant), Komitmen Organisasi, Partisipasi

Anggaran, Penekanan Anggaran

b. Dependent Variable: Senjangan Anggaran

Sumber: Data diolah dari SPSS 21

Berdasarkan tabel 8 hasil uji koefisien determinasi yang digunakan adalah angka adjusted $R^{2}$ yaitu sebesar 0,141 atau $14,1 \%$ yang menunjukan bahwa variabel partisipasi anggaran, penekanan anggaran, dan komitmen organisasi dapat menjelaskan variasi variabel senjangan anggaran sebesar $14,1 \%$ sedangkan sisanya adalah $85,9 \%$ dapat dijelaskan oleh faktor-faktor lain yang tidak diteliti pada penelitian ini seperti kejelasan sasaran anggaran, locus of control, budgetary control, ketidakpastian stratejik, informasi asimetri, ketidakpastian lingkungan, group cohesiveness dan lain-lain.

\section{Uji Simultan (Uji F)}

Pengujian menyeluruh atau uji $\mathrm{F}$ pada dasarnya bertujuan untuk menunjukan apakah seluruh variabel independen (Partisipasi Anggaran, Penekanan Anggaran dan Komitmen Organisasi) secara bersama-sama memiliki pengaruh yang signifikan terhadap variabel dependen (Senjangan Anggaran).

Tabel 9. Hasil Uji F

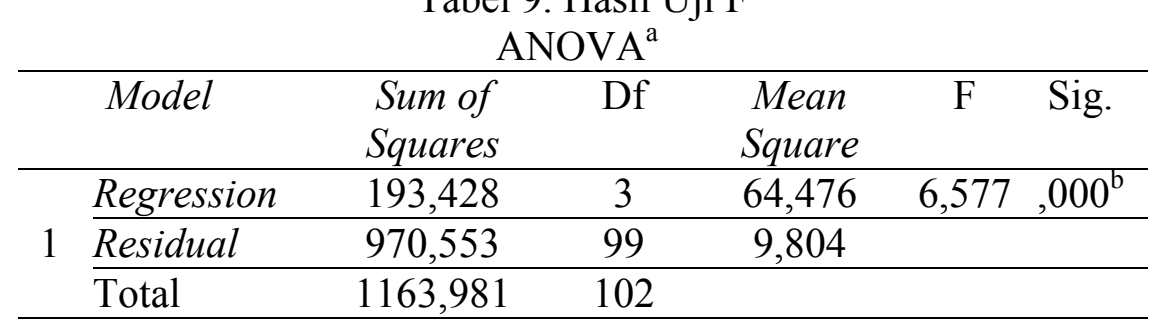

a. Dependent Variable: Senjangan Anggaran

b. Predictors: (Constant), Komitmen Organisasi, Partisipasi

Anggaran, Penekanan Anggaran

Sumber: Data diolah dari SPSS 21

Berdasarkan tabel 9, dapat membandingkan nilai $\mathrm{F}$ hitung sebesar 6,577> F tabel $(2,70)$ dengan tingkat signifikansi $0,000<0,05$ maka dapat disimpulkan bahwa Ho ditolak dan Ha diterima. Hal ini menunjukan bahwa Partisipasi Anggaran, Penekanan 
Anggaran, dan Komitmen Organisasi secara simultan berpengaruh signifikan terhadap Senjangan Anggaran.

\section{Uji t (Uji Parsial)}

Pengujian statistik $\mathrm{t}$ ini pada dasarnya dilakukan untuk mengetahui apakah variabel independen (Partisipasi Anggaran, Penekanan Anggaran, dan Komitmen Organisasi) secara individual atau parsial berpengaruh signifikan terhadap variabel dependen (Senjangan Anggaran). Uji t dilakukan dengan membandingkan antara $t$ hitung dengan $t$ tabel. Berikut adalah hasil pengujian secara parsial (Uji t):

Tabel 10. Hasil Uji t

Coefficients $^{a}$

\begin{tabular}{llcc}
\hline \multicolumn{1}{c}{ Model } & $\mathrm{T}$ & Sig. \\
\hline \multirow{3}{*}{1} & (Constant) & 2,531 &, 013 \\
\cline { 2 - 4 } & Partisipasi Anggaran & 1,708 &, 091 \\
\cline { 2 - 4 } & Penekanan Anggaran &, 156 &, 877 \\
\cline { 2 - 4 } & Komitmen Organisasi & 1,746 &, 084 \\
\hline
\end{tabular}

a. Dependent Variable: Senjangan Anggaran

Sumber: Data diolah dari SPSS 21

Berdasarkan tabel 10 dapat diketahui bahwa variabel partisipasi anggaran mempunyai t hitung sebesar $1,708<1,98422$ dengan signifikansi $0,091>0,05$, hal ini berarti Ho diterima dan Ha ditolak. Maka dapat disimpulkan bahwa variabel partisipasi anggaran tidak terdapat pengaruh yang signifikan terhadap senjangan anggaran.

Variabel penekanan anggaran mempunyai t hitung sebesar 0,156 $<1,98422$ dengan signifikansi 0,877 >0,05, hal ini berarti Ho diterima dan Ha ditolak. Maka dapat disimpulkan bahwa variabel penekanan anggaran tidak terdapat pengaruh yang signifikan terhadap senjangan anggaran.

Variabel komitmen organisasi mempunyai $\mathrm{t}$ hitung sebesar 1,746< 1,98422 dengan signifikansi 0,084 >0,05, hal ini berarti Ho diterima dan Ha ditolak. Maka dapat disimpulkan bahwa variabel komitmen organisasi tidak terdapat pengaruh yang signifikan terhadap senjangan anggaran.

\section{Model Regresi Linier Berganda}

Dalam penelitian ini analisis uji regresi berganda dilakukan untuk mengetahui besarnya pengaruh variabel independen yaitu Partisipasi Anggaran, Penekanan Anggaran, dan Komitmen Organisasi terhadap variabel dependen yaitu Senjangan Anggaran.

Tabel 11. Hasil Regresi Linier Berganda

$$
\text { Coefficients }^{a}
$$

\begin{tabular}{|c|c|c|c|c|c|c|}
\hline \multirow{2}{*}{\multicolumn{2}{|c|}{ Model }} & \multicolumn{2}{|c|}{$\begin{array}{c}\text { Unstandardized } \\
\text { Coefficients }\end{array}$} & \multirow{2}{*}{$\begin{array}{c}\begin{array}{c}\text { Standardized } \\
\text { Coefficients }\end{array} \\
\text { Beta }\end{array}$} & \multirow[t]{2}{*}{$\mathrm{t}$} & \multirow[t]{2}{*}{ Sig. } \\
\hline & & $\mathrm{B}$ & Std. Error & & & \\
\hline \multirow{4}{*}{1} & (Constant) & 7,710 & 3,046 & & 2,531 &, 013 \\
\hline & Partisipasi Anggaran & 235 &, 138 & ,219 & 1,708 & ,091 \\
\hline & Penekanan Anggaran &, 017 &, 111 &, 021 &, 156 & ,877 \\
\hline & Komitmen Organisasi & , 180 & 103 & ,219 & 1,746 & ,084 \\
\hline
\end{tabular}

a. Dependent Variable: Senjangan Anggaran

Sumber: Data diolah dari SPSS 21 
Dari hasil analisis maka dapat diketahui persamaan regresi yang terbentuk sebagai berikut:

$\mathrm{SA}=7,710+0,235 \mathrm{PA}+0,017 \mathrm{PEA}+0,180 \mathrm{KO}$

\section{Pembahasan}

\section{Pengaruh Partisipasi Anggaran Terhadap Senjangan Anggaran}

Berdasarkan hasil uji t dapat disimpulkan bahwa variabel partisipasi anggaran secara parsial tidak terdapat pengaruh yang signifikan terhadap senjangan anggaran. Artinya pihak-pihak yang terlibat dalam proses penyusunan anggaran tidak memberikan informasi bias yang biasa dilakukan dengan meninggikan biaya dan merendahkan pendapatan, sehingga senjangan anggaran yang dapat merugikan suatu instansi tidak terjadi. Hasil penelitian ini sesuai dengan hasil penelitian terdahulu yang dilakukan oleh Alfebriano (2013) dan Amiruddin \& Auzair (2014) yang menunjukkan partisipasi anggaran tidak memiliki pengaruh yang signifikan terhadap senjangan anggaran. Hal ini menunjukan bahwa tinggi atau rendahnya partisipasi anggaran tidak memiliki pengaruh terhadap senjangan anggaran.

\section{Pengaruh Penekanan Anggaran Terhadap Senjangan Anggaran}

Berdasarkan hasil uji t dapat disimpulkan bahwa variabel penekanan anggaran secara parsial tidak terdapat pengaruh yang signifikan terhadap senjangan anggaran. Artinya penekanan di dalam anggaran yang di alami oleh penyusun anggaran tidak membuat pihak yang terlibat dalam proses penyusun anggaran merasa terbebani dengan target anggaran yang ditetapkan. Sehingga praktik senjangan anggaran yang dapat merugikan suatu instansi tidak terjadi. Hasil penelitian ini sesuai dengan hasil penelitian terdahulu yang dilakukan oleh Alfebriano (2013) dan Amiruddin \& Auzair (2014) yang menunjukkan penekanan anggaran tidak memiliki pengaruh yang signifikan terhadap senjangan anggaran. Hal ini menunjukan bahwa tinggi atau rendahnya penekanan anggaran tidak memiliki pengaruh terhadap senjangan anggaran.

\section{Pengaruh Komitmen Organisasi Terhadap Senjangan Anggaran}

Berdasarkan hasil uji t dapat disimpulkan bahwa variabel komitmen organisasi secara parsial tidak terdapat pengaruh yang signifikan terhadap senjangan anggaran. Artinya komitmen organisasi yang dimiliki oleh pihak-pihak yang terlibat dalam proses penyusunan anggaran tidak dapat mempengaruhi senjangan anggaran, hal ini bisa disebabkan karena masih banyaknya faktor-faktor lain yang tidak di teliti dalam penelitian ini yang mampu mempengaruhi senjangan anggaran seperti informasi asimetri, ketidakpastian lingkungan, kejelasan sasaran anggaran dan lain-lain. Hasil penelitian ini sesuai dengan hasil penelitian terdahulu yang dilakukan oleh Alfebriano (2013) yang menunjukan komitmen organisasi tidak memiliki pengaruh yang signifikan terhadap senjangan anggaran. Hal ini menunjukan bahwa tinggi atau rendahnya komitmen organisasi tidak memiliki pengaruh terhadap senjangan anggaran.

\section{Keterbatasan Penelitian}

Beberapa keterbatasan yang ada dalam penelitian ini umumnya pada saat penyebaran kuisioner, diantaranya waktu yang terbatas dalam proses penyebaran kuisioner, masih minimnya kepedulian calon responden terhadap dunia pendidikan 
seperti pengisian kuisioner dan sulitnya untuk mengetahui kejujuran responden dalam menjawab setiap pernyataan-pernyataan yang ada didalam kuisioner.

\section{SIMPULAN}

a. Berdasarkan hasil uji koefisien determinasi diperoleh angka adjusted $\mathrm{R}^{2}$ yaitu sebesar 0,141 atau $14,1 \%$ yang menunjukan bahwa variabel partisipasi anggaran, penekanan anggaran, dan komitmen organisasi dapat menjelaskan variasi variabel senjangan anggaran sebesar $14,1 \%$ sedangkan sisanya adalah $85,9 \%$ dapat dijelaskan oleh faktor-faktor lain yang tidak diteliti pada penelitian ini seperti kejelasan sasaran anggaran, locus of control, budgetary control, ketidakpastian stratejik, informasi asimetri, ketidakpastian lingkungan, group cohesiveness dan lain-lain.

b. Secara simultan variabel partisipasi anggaran, penekanan anggaran, dan komitmen organisasi berpengaruh signifikan terhadap senjangan anggaran. Jadi partisipasi dalam penyusunan anggaran, adanya penekanan dari atasan terhadap bawahan serta tingkat komitmen organisasi yang dimiliki responden akan meningkatkan senjangan anggaran.

c. Secara parsial variabel partisipasi anggaran tidak memiliki pengaruh yang signifikan terhadap senjangan anggaran, artinya tinggi atau rendahnya partisipasi anggaran tidak memiliki pengaruh terhadap naik atau turunnya senjangan anggaran atau tidak mempengaruhi senjangan anggaran.

d. Secara parsial variabel penekanan anggaran tidak memiliki pengaruh yang signifikan terhadap senjangan anggaran, artinya tinggi atau rendahnya penekanan anggaran tidak memiliki pengaruh terhadap naik atau turunnya senjangan anggaran atau tidak mempengaruhi senjangan anggaran.

e. Secara parsial variabel komitmen organisasi tidak memiliki pengaruh yang signifikan terhadap senjangan anggaran, artinya tinggi atau rendahnya komitmen organisasi setiap individu tidak memiliki pengaruh terhadap naik atau turunnya senjangan anggaran atau tidak mempengaruhi senjangan anggaran.

\section{Saran}

Berdasarkan hasil penelitian dan informasi yang diperoleh saat penyebaran kuisioner, dapat diajukan beberapa saran yaitu sebagai berikut:

a. Pihak legislatif harus turut aktif dalam proses penyusunan anggaran dan pengawasan anggaran. Sehingga praktik senjangan anggaran yang dapat membuat kerugian negara dapat di minimalisir.

b. Penilaian kinerja sebaiknya tidak hanya dinilai melalui pencapaian target anggaran saja, sehingga pihak penyusun anggaran tidak merasa terbebani dengan target anggaran yang dibuat.

c. Kordinasi yang baik antar pihak-pihak yang terlibat dalam proses penyusunan anggaran harus ditingkatkan, hal ini bertujuan untuk terciptanya anggaran yang berkualitas. 


\section{DAFTAR PUSTAKA}

, Undang-Undang Nomor 32 Tahun 2004 tentang Pemerintah Daerah.

, Undang-Undang Nomor 15 Tahun 2004 tentang Pemeriksaan Pengelolaan dan Tanggung Jawab Keuangan Negara.

, Undang-Undang Nomor 17 Tahun 2003 tentang Keuangan Negara.

\section{Pemerintah.}

, Peraturan Pemerintah No 71 Tahun 2010 tentang Standar Akuntansi

Ajibolade, S.O. (2013). The Influence of Organisational Culture and Budgetary Participation on Propensity to Create Budgetary Slack in Public Sector Organisations. British Journal of Arts and Social Sciences, vol.13, no.1. page. 69-83.

Alfebriano. (2013). Faktor-Faktor yang Mempengaruhi Slack Anggaran Pada PT. BRI di Kota Jambi. E-Jurnal Binar Akuntansi, vol. 2, no. 1, Januari 2013, hlm. $10-18$.

Amiruddin, R., \& Auzair, S.M. (2014). Impact of Organisational Factors on Budgetary Slack. E-proceedings of the Conference on Management and Muamalah, (CoMM 2014), 26-27 May 2014, page. 20-34.

Apriantini, N.K.E., Adiputra, I.M.P., \& Sujana, E. (2014). Pengaruh Partisipasi Anggaran Terhadap Senjangan Anggaran Dengan Penekanan Anggaran dan Komitmen Organisasi Sebagai Variabel Moderating. e-Journal S1 Ak Universitas Pendidikan Ganesha, vol. 2, no. 1 Tahun 2014.

Bastian, I. (2010). Akuntansi Sektor Publik Suatu Pengantar. edisi ketiga, Yogyakarta: Erlangga.

Blocher, E.J., Stout, D.E., \& Cokins, G. (2011). Manajemen Biaya Penekanan Strategis. edisi 5, buku 1, Jakarta: Salemba Empat.

Bulan, R.F. (2011). Pengaruh Partisipasi Anggaran dan Kejelasan Sasaran Anggaran Terhadap Job Relevant Information Serta Implikasinya Pada Senjangan Anggaran. Jurnal Telaah \& Riset Akuntansi, vol. 4, no. 1, Januari 2011, hlm. 33-50.

Carina, J. (2015). DPRD Sentil Dinas Kelautan DKI, Anggaran Olahraga Jumat Pagi Rp. 258 Juta. Diakses 26 Desember 2015. Dari http://megapolitan.kompas.com/read/2015/09/17/09020951/DPRD.Sentil.Dina s.Kelautan.DKI.Anggaran.Olahraga.Jumat.Pagi.Rp.258.Juta.

Cook, J., \& Wall, T. (1980). New Work Attitude Measures of Trust, Organizational Commitment and Personal Need Non-Fulfilment, Journal of Occupational Psychology. 1980, 53, Printed in Great Britain, page. 39-52. 
Dewi, N.M.C., \& Sudana, I.P. (2013). Pengaruh Penganggaran Partisipatif Pada Senjangan Anggaran Dengan Budgetary Control dan Komitmen Organisasi Sebagai Variabel Pemoderasi. E-Jurnal Akuntansi Universitas Udayana, vol. 5, no. 3, hlm. 707-722.

Dewi, N.P., \& Erawati, N.M.A. (2014). Pengaruh Partisipasi Penganggaran, Informasi Asimetris, Penekanan Anggaran dan Komitmen Organisasi Pada Senjangan Anggaran. E-Jurnal Akuntansi Universitas Udayana, vol. 9, no.2, hlm. 467-486.

Fahmi, I., \& Hadi, Y.L. (2009). Teori Portofolio dan Analisis Investasi. Bandung: Alfabeta.

Garrison, R.H., Norren, E.W., \& Brewer, P.C. (2013). Akuntansi Manajerial. edisi 14, buku 2, Jakarta: Salemba empat.

Ghozali, I. (2013). Aplikasi Analisis Multivariate Dengan Program IBM SPSS 21. Semarang: Universitas Diponegoro.

Halim, A., \& Kusufi, H.S. (2014). Teori, Konsep, dan Aplikasi Akuntansi Sektor Publik Dari Anggaran Hingga Laporan Keuangan Dari Pemerintah Hingga Tempat Ibadah. edisi 2, Jakarta: Salemba Empat.

Harahap, S.S. (2012). Teori Akuntansi, Edisi Revisi 2011. Jakarta: Rajawali Pers.

Ikhsan, A., \& Ane, L. (2007). Pengaruh Partisipasi Anggaran Terhadap Senjangan Anggaran Dengan Menggunakan Lima Variabel Pemoderasi. Simposium Nasional Akuntansi X, Makasar 2007, hlm. 1-27.

Lubis, A.I. (2010). Akuntansi Keperilakuan. edisi 2, Jakarta: Salemba Empat.

Mahadewi, A.A.S.S. (2014). Pengaruh Partisipasi Penganggaran Pada Senjangan Anggaran Dengan Asimetri Informasi dan Komitmen Organisasi Sebagai Pemoderasi. E-Jurnal Akuntansi Universitas Udayana 8.3, hlm. 458-473.

Mardiasmo. (2009). Akuntansi Sektor Publik. Yogyakarta: Penerbit Andi.

Putranto, Y.A. (2012). Pengaruh Moderasi Informasi Asimetri dan Group Cohesiveness Terhadap Hubungan Partisipasi Penganggaran Dengan Budgetary Slack. Jurnal Economia, Volume 8, Nomor 2, Oktober 2012, hlm. 116-125.

Rahayu, S., \& Rachman, A.A. (2013). Penyusunan Anggaran Perusahaan. Yogyakarta: Graha Ilmu.

Savitri, E., \& Sawitri, E. (2014). Pengaruh Partisipasi Anggaran, Penekanan Anggaran, dan Informasi Asimetri Terhadap Timbulnya Kesenjangan Anggaran. Jurnal Akuntansi, vol. 2, no. 2, April 2014, hlm. 210-226. 
Siregar, B., Suripto, B., Hapsore, D., Lo, E.W., Biyanto., \& Frasto. (2013). Akuntansi Manajemen. Jakarta: Salemba Empat.

Sugiyono (2011). Metode Penelitian Kombinasi (Mixed Methods). Bandung: Alfabeta.

Sujarweni, V.W. (2012). SPSS Untuk Paramedis. Yogyakarta: Gava Media.

Triana, M., Yuliusman., \& Putra, W.E. (2012). Pengaruh Partisipasi Anggaran, Budget Emphasis, dan Locus of Control Terhadap Slack Anggaran. e-Jurnal Binar Akuntansi, vol. 1, no. 1, September 2012, hlm. 51-56.

Young, S.M. (1985). Participative Budgeting: The Effects of Risk Aversion and Asymmetric Information on Budgetary Slack. Journal of Accounting Research, vol. 23, no. 2, Januari 2008, page. 829-842. 